\title{
Relative abundance of stem borer species and natural enemies in rice ecosystem at Madhupur, Tangail, Bangladesh
}

\author{
M. M. Rahaman*, K.S. Islam, M. Jahan and M. A. A. Mamun \\ Department of Entomology, Bangladesh Agricultural University, Mymensigh-2202, Bangladesh, *E-mail address: \\ m_rahaman06@yahoo.com
}

\begin{abstract}
The relative abundance of different stem borer species and their natural enemies with interaction effects were studied at three growth stages of irrigated Boro rice at Madhupur under the district of Tangail, Bangladesh during January to April, 2013. Five stem borer species viz; Yellow stem borer (Scirpophaga incertulas), Pink stem borer (Sesamia inferens), Dark headed stem borer (Chilo polyhcrysus), Stripped stem borer (Chilo suppressalis), White stem borer (Scirpophaga innotata), and nine different natural enemies were collected from the rice fields and recorded. The population of stem borers and natural enemies was highest in tillering stage and lowest in seedling stage. The relative abundance of stem borer species under investigation showed ranking order; yellow stem borer $>$ dark headed stem borer>pink borer>white borer>stripped stem borer and natural enemies as ladybird beetle >long jawed spider>wolf spider>damselfly $>$ carabid beetle>green mirid bug $>$ lynx spider>dragon fly $>$ ear wig. Populations of all five stem borers were positively correlated with ladybird beetle, wolf spider, long jawed spider, lynx spider, damsel fly, dragon fly, green mirid bug and negatively correlated with carabid beetle and earwig.
\end{abstract}

Keywords: Stem borers, Natural enemies, Relative abundance, Rice ecosystem

\section{Introduction}

Rice (Oryza sativa L.) is one of the world's most important crops providing a staple food for nearly half of the global population (FAO, 2004). It is the major food crop of Bangladesh accounting for 70 percent of the cultivated area, 78 percent of the irrigated area, 52 percent of the agricultural GDP and 71 percent of the caloric intake (Hassan and Bakshi, 2005). Rice is grown in three seasons in Bangladesh that includes Aus (April-July), Amon (July-December) and Boro (December-April). Research has contributed significantly in achieving food security by increasing the yield potential of rice through development of HYV's (Hassan and Fischer, 1995). The demand for rice is constantly rising to feed the ever growing population of the country. In producing more rice, farmers are using modern varieties, fertilizers, pesticides, water and other technologies intensively which have eventually changed the ecology and escalated pest proliferation (Parvin, 2010).

Among various constraints for good rice production, infestation of different insect species is very important. The rice plant is attacked by more than 100 species of insects and 20 of them can cause serious economic loss (Pathok, 1977). Yield loss due to insect pests of rice has been estimated about 30$40 \%$ (Henrich et al., 1979). The rice stem borers are the principal devastators and responsible for economic crop losses under field condition (Mahar and Hakro, 1979). They are common and serious pests in Asian countries responsible for annual damages of 5-10\% of rice crops (Pathok and Khan, 1994). Heavily infestation may cause yield loss up to $80 \%$ (Rubia-Sanchez et al.. 1997). Five species of rice stem borers have been identified available in South East-Asia namely; Dark headed stem borer (DHSB), Chilo polychrysus (Meyrick); Yellow stem borer (YSB), Scirpophaga incertulas (Walker); Pink stem borer (PSB), Sesamia inferens (Walker); Stripped stem borer (SSB), Chilo supressalis (Meyrick) and White borer (WB), Scirpophaga innotata (Walker) (DRR, 2006). YSB is the most destructive insect pests of rice crop (Mahar et al., 1985) and responsible for an annual yield loss of $10-15 \%$ with local catastrophic outbreaks causing up to $60 \%$ damage (Catling and Islam, 1981 and Daryaei, 2005). It is the most important insect pest of rice in Bangladesh (Islam and Hassan, 1999) and also considered a major pest in Asia (Torri, 1971).

A field guide developed by Shepard et al. (1987) illustrates that the natural enemies of rice pests are actually friends of the rice farmers. Use of insecticides continues to be the major tactic employed by rice growers to minimize the yield losses from this pest. Conservation of natural enemies; predators, parasitoids and entomopathogens etc, is an important component of modern integrated pest management (IPM). Pesticides that are less harmful to natural enemies can be also effective tools for IPM. Rahman (2013) and Islam (2012) evaluated the botanicals and chemical insecticides for their side 
effects on natural enemies of rice. The botanical extracts were found less harmful than chemical insecticides. The insecticides and botanicals reduced the infestation of YSB and significantly influenced the yield performance of rice.

Pest and natural enemy populations fluctuate due to various environmental factors, locations, rice varieties, seasons and plant ages and insecticides usage (BRRI Annual Report, 2005-2006). Dominant hunting spiders reach peak during 60 to 75 DAT and their population further declines with the age of the crop. Spider shows significant positive correlation with BPH during Kharif season in all locations and they shows no interactions with YSB (Venkateshlu, 2008)

Considering the yield loss due to stem borers and significant role of natural enemies in rice ecosystem, an attempt was made to design a survey experiment to observe the relative abundance of stem borers and natural enemies in boro rice in one upazila of Tangail. The present study was conducted to gather information in order to develop elements of an integrated control program against rice stem borers by the farmers in the local cropping system, characterized by the relationship between the pests and natural enemies. Population density of borer pest complex in different growth stages of the rice plant would be useful to decide appropriate time of insecticide application. The specific objective of this study was to assess the abundance and diversity of stem borers and natural enemies in rice.

\section{Materials and Methods}

The survey experiment was conducted to determine the relative abundance of stem borers and natural enemies in irrigated rice fields of Bangladesh Agricultural Development Corporation (BADC) at Madhupur under Tangail district during Boro season, January to April, 2013. The experimental plot was located close to the Madhupur sal forest which possesses a great ecological impact with a rich biodiversity of diverse flora and fauna (Taher et al., 2009). A total of 3 field visits were made to collect data. The insect pests of rice and their natural enemies were collected by a fine nylon cloth sweep net (30 cm dia.). Sweeping was done from the plant canopy level including the interspaces between plants as well as close to basal region of the plants as far as possible. In each field, 20 complete sweeps were made to collect the insect pests and natural enemies for a single sample. Three replications were made for each plant stage (Seedling, Tillering and Heading stage) from the randomly selected rice fields. Sampling was done during morning hours at all experimental fields. The stem borer species and natural enemies of each sample were separated and left in labeled containers containing $70 \%$ alcohol. The collected samples were counted carefully and identified. Relative abundance of rice stem borers and natural enemies was calculated using the following formula:

$$
\text { Relative abundance }(\%)=\frac{\text { Total no. of individuals of each species }}{\text { Total no. of individuals of all species }} \times 100
$$

Statistical analysis of data was performed using Microsoft Office Excel in Windows. Correlation coefficient ( $r$ ) was calculated to describe a correlation between two or more variables. Student's t-test was used to find a difference in mean.

\section{Results and Discussion}

The results of the research are shown bellow. Abundance of stem borers and natural enemies at different growth stages are presented in the Table 1A, 1B, 2A and 2B. Correlations among stem borer species and natural enemies are also presented in the Table 3.

\section{Abundance of stem borers as influenced by different growth stages of rice (Table 1A \& 1B)}

Pink borer: Pink borer differed significantly among different growth stages of rice showing the relative abundance of $8.08 \%$ with means ranged from 1.47 to 3.17 per 20 complete sweeps. Highest number of pink borer was recorded in tillering stage (3.17) and lowest number was found in seedling stage (1.47).

Dark headed stem borer: Dark headed stem borer differed significantly among different growth stages with relative abundance of $14.36 \%$. Highest number of dark headed stem borer was recorded in tillering stage (6.42) and lowest was recorded in seedling stage (2.08). 
Yellow stem borer: The populations of yellow stem borer differed significantly among different rice growth stages showing the relative abundance $69.90 \%$. The highest number of yellow stem borer was found in tillering stage (30.17) and lowest in seedling stage (12.08).

Stripped stem borer: The populations of stripped stem borer differed significantly among different rice growth stages with the relative abundance of $2.75 \%$. The highest number of stripped stem borer was found in tillering stage (1.17) and lowest in seedling stage (0.376).

White borer: The populations of white borer differed significantly among different rice growth stages with the relative abundance of $4.91 \%$. The highest number of stripped stem borer was found in tillering stage (1.92) and lowest in seedling stage (1.003).

Rajini et al. (2000) observed 3 rice stem borer species, i.e. the YSB (Scirpophaga incertulas), PSB (Sesamia inferens) and DHB (Chilo polychrysus) and found that YSB was the most predominant species in June to September (60.0\%) and October to January (48.43\%). PSB was the second most predominant species in June-September (35.21\%) and as abundant as YSB in October to January (48.43\%). DSB was least abundant during either season (4.29-7.18\%). The differences among the results might be due to the environmental condition or might be due to the population's pressure of other species.

Table 1A. The abundance of adult rice stem borers at different growth stages of rice per 20 complete sweeps

\begin{tabular}{|l|c|c|c|c|c|}
\hline Growth stage & $\begin{array}{c}\text { Pink borer } \\
(\mathrm{PB}) \\
(\text { mean no. })\end{array}$ & $\begin{array}{c}\text { Dark headed stem } \\
\text { borer (DHSB) } \\
\text { (mean no.) }\end{array}$ & $\begin{array}{c}\text { Yellow stem } \\
\text { borer (YSB) } \\
\text { (mean no.) }\end{array}$ & $\begin{array}{c}\text { Stipped stem } \\
\text { borer (SSB) } \\
\text { (mean no.) }\end{array}$ & $\begin{array}{c}\text { White stem } \\
\text { borer (WB) } \\
\text { (mean no.) }\end{array}$ \\
\hline Seedling stage & $1.47 \mathrm{c}$ & $2.08 \mathrm{c}$ & $12.08 \mathrm{c}$ & $0.376 \mathrm{c}$ & $1.003 \mathrm{c}$ \\
\hline Tillering stage & $3.17 \mathrm{a}$ & $6.42 \mathrm{a}$ & $30.17 \mathrm{a}$ & $1.17 \mathrm{a}$ & $1.92 \mathrm{a}$ \\
\hline Heading stage & $2.49 \mathrm{~b}$ & $4.17 \mathrm{~b}$ & $19.42 \mathrm{~b}$ & $0.893 \mathrm{~b}$ & $1.42 \mathrm{~b}$ \\
\hline Level of significance & $\star \star$ & $\star \star$ & $\star \star$ & $\star \star$ & $\star \star$ \\
\hline LSD $_{0.05}$ & 0.237 & 0.358 & 1.92 & 0.071 & 0.277 \\
\hline
\end{tabular}

** $=$ Significant at $1 \%$ level of probability

Table 1B. Relative abundance of different species of stem borer (\%)

\begin{tabular}{|c|c|c|}
\hline Name of insects & Total (No.) & Relative abundance (\%) \\
\hline Pink borer (PB) & 7.13 & 8.08 \\
\hline Dark headed stem borer (DHSB) & 12.67 & 14.36 \\
\hline Yellow stem borer (YSB) & 61.67 & 69.90 \\
\hline Stipped stem borer (SSB) & 2.43 & 2.75 \\
\hline White stem borer (WB) & 4.33 & 4.91 \\
\hline Total & 88.23 & \\
\hline
\end{tabular}

Rank order of relative abundance of rice stem borers: YSB (69.90\%) > DHSB (14.36\%) > PB (8.08\%) $>$ WB $(4.91 \%)>$ SSB $(2.75 \%)$

\section{Abundance of natural enemies as influenced by different growth stages of rice (Table 2A \& 2B)}

Carabid beetle ( Ophonea indica): The population of carabid beetle differed significantly among different growth stages in boro rice showing relative abundance of $5.81 \%$ with means ranged from 4.00 to 13.33 per 20 complete sweeps. The highest mean number of carabid beetle was recorded in seedling stage (13.33) and lowest in heading stage (4.00).

Ladybird beetle: Ladybird beetle, Micraspis discolor were found dominant in rice growing season. This species was taken into consideration in this experiment. Ladybird beetle differed significantly among different stages with $49.95 \%$ relative abundance. The highest number was found in tillering stage (130.70) and lowest number was found in seedling stage (13.67). This result was not in agreement with the finding of Rahman et al. (1991). They found that increasing number of LBB (M. discolor) was noticed at the flowering stage of rice. In the result of present study, the highest number of ladybird beetle found at tillering stage might be due to the sufficient number of prey. 
Spiders: Three species of spider were found dominant during the crop growing season.

Wolf spider differed significantly among different stages with the relative abundance of $7.87 \%$. The highest number was found in tillering stage (16.87) and lowest in heading stage (10.33).

Long jawed spider differed significantly among different stages with the relative abundance of $17.82 \%$. The highest number was recorded in tillering stage (46.33) and lowest in seedling stage (5.30).

No significant differences were found in lynx spider population in different growth stages of boro rice having relative abundance of $2.83 \%$. The lowest number was recorded in heading stage (3.00) which was statistically identical with the number recorded in both tillering stage (5.87) and seedling stage (5.00).

The results were similar with the findings reported by Kawahara et al. (1968). They observed that approximately 1-7 spiders were found per hill and each spider preys upon 2 leaf hopper per day. They also reported that the invasion of spiders into paddy field was prolonged beyond 20 to 60 days after transplanting and most species peaked in immediately before harvest.

Damselfly: Damselfly populations showed significant differences in various growth stages with the relative abundance of $6.26 \%$. The highest number was recorded in tillering stage (12.33) and lowest in seedling stage (7.67)

Dragonfly: No significant differences were found in dragonfly populations in different growth stages of boro rice showing $2.30 \%$ relative abundance. The highest number was found in heading stage (4.33) which was statistically identical with the number recorded in seedling stage (3.00) and tillering stage (3.95).

Green Mirid Bug: Significant differences were found in mirid bug populations with the relative abundance of $4.94 \%$. The highest number of green mirid bug was recorded in heading stage (10.67) and lowest in seedling stage (3.67).

Earwig: Ear wig populations also differed significantly among different growth stages of boro rice showing the relative abundance of $2.21 \%$. The highest number was found in seedling stage (4.80) and lowest in heading stage (2.33).

Table 2A. The incidence of natural enemies at different growth stages of rice in per 20 complete sweeps

\begin{tabular}{|c|c|c|c|c|c|c|c|c|c|}
\hline Growth stage & $\begin{array}{c}\text { Carabid } \\
\text { beetle } \\
(\mathrm{CB}) \\
\text { (mean) }\end{array}$ & $\begin{array}{l}\text { Ladybird } \\
\text { beetle } \\
\text { (LBB) } \\
\text { (mean) }\end{array}$ & $\begin{array}{l}\text { Wolf } \\
\text { spider } \\
\text { (WS) } \\
\text { (mean) }\end{array}$ & $\begin{array}{l}\text { Long jawed } \\
\text { spider (LJS) } \\
\text { (mean) }\end{array}$ & $\begin{array}{l}\text { Lynx } \\
\text { spider } \\
\text { (LS) } \\
\text { (mean) }\end{array}$ & $\begin{array}{c}\text { Damsel } \\
\text { fly (DSF) } \\
\text { (mean) }\end{array}$ & $\begin{array}{c}\text { Dragon fly } \\
\text { (DRF) } \\
\text { (mean) }\end{array}$ & $\begin{array}{c}\text { Green } \\
\text { Mirid Bug } \\
\text { (GMB) } \\
\text { (mean) } \\
\end{array}$ & $\begin{array}{c}\text { Ear wig } \\
\text { (EW) } \\
\text { (mean) }\end{array}$ \\
\hline Seedling stage & $13.33 \mathrm{a}$ & $13.67 \mathrm{c}$ & $11.33 \mathrm{~b}$ & $5.30 \mathrm{c}$ & 5.00 & $7.67 \mathrm{~b}$ & 3.00 & $3.67 \mathrm{~b}$ & $4.80 \mathrm{a}$ \\
\hline Tillering stage & $11.11 \mathrm{~b}$ & $130.70 \mathrm{a}$ & $16.87 \mathrm{a}$ & $46.33 \mathrm{a}$ & 5.87 & $12.33 \mathrm{a}$ & 3.95 & $9.87 \mathrm{a}$ & $3.70 \mathrm{~b}$ \\
\hline Heading stage & $4.00 \mathrm{c}$ & $100.30 \mathrm{~b}$ & $10.33 \mathrm{~b}$ & $35.67 b$ & 3.00 & $10.67 \mathrm{a}$ & 4.33 & $10.67 \mathrm{a}$ & $2.33 \mathrm{c}$ \\
\hline $\begin{array}{l}\text { Level of } \\
\text { significance }\end{array}$ & $\star \star$ & $\star \star$ & $\star \star$ & $\star \star$ & NS & $\star \star$ & NS & $\star \star$ & $\star \star *$ \\
\hline $\mathrm{LSD}_{0.05}$ & 0.713 & 5.51 & 1.80 & 3.23 & - & 1.92 & - & 0.842 & 0.906 \\
\hline
\end{tabular}

**= Significant at 1\% level of probability

NS $=$ Not significant.

Table 2B. Relative abundance of natural enemies (\%)

\begin{tabular}{|l|c|c|}
\hline \multicolumn{1}{|c|}{ Name of insects } & Total (No.) & Relative abundance (\%) \\
\hline Carabid beetle (CB) & 28.44 & 49.81 \\
\hline Ladybird beetle (LBB) & 244.67 & 7.87 \\
\hline Wolf spider (WS) & 38.53 & 17.82 \\
\hline Long jawed spider (LJS) & 87.30 & 2.83 \\
\hline Lynx spider (LS) & 13.87 & 6.26 \\
\hline Damsel fly (DSF) & 30.67 & 2.30 \\
\hline Dragon fly (DRF) & 11.28 & 4.94 \\
\hline Green Mirid Bug (GMB) & 24.21 & 2.21 \\
\hline Ear wig (EW) & 10.83 & \\
\hline Total & 489.80 & \\
\hline
\end{tabular}


Rank order of relative abundance of natural enemies in boro rice fields: LBB $(49.95 \%)>$ LJS $(17.82 \%)>$ WS $(7.87 \%)>\operatorname{DSF}(6.26 \%)>$ CB $(5.81 \%)>$ GMB $(4.94 \%)>$ LS $(2.83 \%)>$ DRF $(2.30 \%)>$ EW (2.21\%) (Table2B)

Correlation matrix between rice stem borers and natural enemies: The relationship between rice stem borer and natural enemies were determined and their relationships were arranged on the correlation matrix (Table 3).

Populations of pink borer were positively correlated with ladybird beetle (0.988), wolf spider $(0.710)$, long jawed spider (0.979), lynx spider (0.184), damsel fly (0.999), dragonfly (0.771), green mirid bug (0.871) and negatively correlated with carabid beetle $(-0.338)$ and earwig $(-0.544)$ populations.

Populations of dark headed stem borer were positively correlated with ladybird beetle (0.958), wolf spider (0.799), long jawed spider (0.949), lynx spider (0.316), damselfly (0.983), dragonfly (0.678), green mirid bug $(0.796)$ and negatively correlated with carabid beetle $(-0.207)$ and earwig $(-0.425)$ populations.

Yellow stem borer populations were positively correlated with ladybird beetle (0.929), wolf spider (0.849), long jawed spider (0.935), lynx spider (0.397), damsel fly (0.963), dragonfly (0.611), green mired bug $(0.741)$ and negatively correlated with carabid beetle $(-0.121)$ and earwig $(-0.345)$ populations.

Populations of stripped stem borer were positively correlated with ladybird beetle (0.995), wolf spider (0.669), long jawed spider (0.989), lynx spider (0.128), damselfly (0.999), dragonfly (0.806), green mirid bug $(0.898)$ and negatively correlated with carabid beetle $(-0.391)$ and earwig $(-0.591)$ populations.

White stem borer populations were also positively correlated with ladybird beetle (0.945), wolf spider (0.823), long jawed spider (0.937), lynx spider (0.355), damsel fly (0.974), dragonfly (0.647), green mirid bug $(0.771)$ and negatively correlated with carabid beetle $(-0.166)$ and earwig $(-0.387)$ populations.

The results indicate that the populations of all stem borers under investigation induced the populations of ladybird beetle, wolf spider, long jawed spider, lynx spider, damsel fly, dragon fly and mirid bug. It also revealed that carabid beetle and earwig reduced the populations of the stem borers.

From this study, it is concluded that stem borers and natural enemies had very good correlation in the rice ecosystem. Therefore, it is not always necessary to apply insecticides indiscriminately. Present study also confirmed that a good number of friendly insects are always remain in the rice field, therefore, farmer should select reduced risk insecticides if really needed.

Table 3. Correlation matrix among different rice stem borers and natural enemies in boro rice fields

\begin{tabular}{|l|c|c|c|c|c|c|c|c|c|}
\hline & $\begin{array}{c}\text { Carabid } \\
\text { beetle } \\
\text { (CB) }\end{array}$ & $\begin{array}{c}\text { Ladybird } \\
\text { beetle } \\
\text { (LBB) }\end{array}$ & $\begin{array}{c}\text { Wolf } \\
\text { spide } \\
\text { (WS) }\end{array}$ & $\begin{array}{c}\text { Long jawed } \\
\text { spider } \\
\text { (LJS) }\end{array}$ & $\begin{array}{c}\text { Lynx } \\
\text { spider } \\
\text { (LS) }\end{array}$ & $\begin{array}{c}\text { Damsel } \\
\text { fly } \\
\text { (DSF) }\end{array}$ & $\begin{array}{c}\text { Dragon } \\
\text { fly } \\
\text { (DRF) }\end{array}$ & $\begin{array}{c}\text { Green } \\
\text { Mirid Bug } \\
\text { (GMB) }\end{array}$ & $\begin{array}{c}\text { Ear wig } \\
\text { (EW) }\end{array}$ \\
\hline Pink orer (PB) & -0.338 & 0.988 & 0.710 & 0.979 & 0.184 & 0.999 & 0.771 & 0.871 & -0.544 \\
\hline $\begin{array}{l}\text { Dark headed stem borer } \\
\text { (DHSB) }\end{array}$ & -0.207 & 0.958 & 0.799 & 0.949 & 0.316 & 0.983 & 0.678 & 0.796 & -0.425 \\
\hline $\begin{array}{l}\text { Yellow stem borer } \\
\text { (YSB) }\end{array}$ & -0.121 & 0.929 & 0.849 & 0.935 & 0.397 & 0.963 & 0.611 & 0.741 & -0.345 \\
\hline $\begin{array}{l}\text { Stripped stem borer } \\
\text { (SSB) }\end{array}$ & -0.391 & 0.995 & 0.669 & 0.989 & 0.128 & 0.999 & 0.806 & 0.898 & -0.591 \\
\hline White stem borer (WB) & -0.166 & 0.945 & 0.823 & 0.937 & 0.355 & 0.974 & 0.647 & 0.771 & -0.387 \\
\hline
\end{tabular}




\section{References}

BRRI, 2005-2006. Bangladesh Rice Research Institute (BRRI Annual Report, 2005-2006; pp: 142- 146.

Catling, H.D. and Islam, Z. 1981. Problem of yellow stem borer in Asam deep water rice. Proc. Int. Rice Res. Inst. $451-458$.

Daryaei, M.G. 2005. Assessment of yield loss in rice due to yellow stem borer, Scirpophaga incrtulas using Smalton Models. Caspian J. Environ. Sci. 59:62.

DRR, 2006. Insecticides In Rice IPM-Past, Present and Future. Technical Bulletin no. 30, Directorate of Rice Research, Hyderabad, A.P. India. pp: 146.

FAO, 2004. The State of Food Security in the World, Food and Agriculture Organization (FAO), Rome, Italy. pp. 30-31.

Hassan, A. S. M. R. and Bakshi, K. 2005. Pest management, productivity and environment: a comparative study of IPM and conventional farmers of Northern Districts of Bangladesh. Pakistan Journal of Social Sciences. 3:1007-1014.

Heinrichs, E.A., Sexena, R.C. and Chelliah, S. 1979. Development and implementation of insect pests management systems for rice in tropical Asia. ASPAC Bulletin 127. Taiwan: Food and fertilizer technology center.

Hossain, M. and Fischer, K.S. 1995. Rice research for food security and sustainable agricultural development in Asia: achievements and future challenges. Geo-journal. 35:286-298.

Islam, M. S. 2012. Evaluation of different insecticides and botanical extracts against yellow stem borer, Scirpophaga incertulas (Walk) and its natural enemies in rice field. M. S. Thesis (November, 2012), Dept. of Entomology, Bangladesh Agricultural University, Mymensingh.

Islam, Z. and Hasan, M. 1999. Pests of rice in Bangladesh: Present management scenario and future challenges. Proc. First Agric. Cont. CARE Bangladesh Dhaka. pp. 90-98.

Kawahara, S., Kritant, K., Sasaba, T., Naka-Sufig, F. and Okuma, C. 1968. Seasonal changes in abundance and the faunal composition of spiders in the paddy fields with special references to their relation, to the seasonal prevalence of the green leafhopper, Nephotettix cinticeps Uhler. In Proc.Ass. PI. Prot. Sikoku. 4:33-44.

Mahar, M. M. and Hakro, M.R. 1979. The prospects and possibilities of yellow rice stem borer eradication under Sindh condition. Paper presented at the Rice Research and Production Sem. Islamabad. 18- 22, February.

Mahar, M. N., Bratti, I. M. Dhuyo, A.R. 1985. Stem borer infestation and yield loss relationship in rice and cost- benefit of control. Paper presented at $5^{\text {th }}$ National Seminar on rice production. April 23-25.

Parvin, 2010. Rice farmers' knowledge about the effects of pesticides on environmental pollution in Bangladesh. Bangladesh Res. Pub. J. :1214-1227. Retrieve from http://www.bdresearchpublications. com/admin/journal/upload/09129/09129.pdf

Pathok, M. D. 1977. Defense of the rice against insect pests. Ann. N.Y. Acad. Sci., 287-295.

Pathok, M.D. and Khan, Z.R. 1994. Insect pests of rice. International Rice Research Institute, Los Banos, Philippines.

Ragini, J.C., Thangaraju, D. and David, P.M.M. 2000. Relative abundance of rice stem borer species in Tamil nadu. Madras Agril. J. Publ. 2001.87(4-6):228-234.

Rahman, M. H., Sardar, M. A. and Haque, M. R. 1991. Population dynamics of Micraspis discolor (Coccinellidae: Coleoptera) in rice and its susceptibility to insecticides. Bangladesh J. Entomol. 1:27-33.

Rahman, M. M. 2013. Eco- friendly management of rice yellow stem borer, Scirpophaga incertulas (Pyralidae: Lepidoptera) through reducing risk of insecticides. M. S. Thesis (June:2013), Department of Entomology, Bangladesh Agricultural University, Mymensingh.

Rubia-Sanchez , E.G., Nurhasyim, D., Heong, K.L., Zaluki, M., Norton, G.A. 1997. What stem borer damage and grain yield in irrigated rice in west Java, Indonesia. Crop protect. 16, 665-671.

Shepard, B.M.; Barrion, A.T. and Litsinger, J.A. 1987. Helpful insects, spiders and pathogens; friends of the farmer (BNG). Los Banos, Laguna, IRRI. 123.

Taher, M. A., Sattar, M.A., Rahaman, M.M. and Alom, M.M. 2009. Biodiversity of Madhupur Forerst. J. Bangladesh Soc. Agric. Sci. Technol., 6(1\&2): 217-222.

Torii, T. 1971. The ecological studies of rice stem borers in Japan: a new review Mushi. 45: 1-49.

Venkateshlu.; Sannveerappanavar, T. and Nagaraja, M.V. 2008. Population fluctuation of spiders in rice ecosystem in relation to pest density and weather parameters, Mysore journal of Agricultural Sciences, 42(2):233-240. 